\title{
Climate, people and faunal succession on Java, Indonesia: evidence from Song Gupuh
}

\author{
M.J. Morwood ${ }^{\text {a,c,*, T. Sutikna }}{ }^{\text {b }}$, E.W. Saptomo ${ }^{\text {b }}$, K.E. Westaway ${ }^{\text {a }}$, Jatmiko ${ }^{\text {, }}$, \\ R. Awe Due ${ }^{\mathrm{b}}$, M.W. Moore ${ }^{\mathrm{c}}$, Dwi Yani Yuniawati ${ }^{\mathrm{b}}$, P. Hadi ${ }^{\mathrm{d}}, \mathrm{J}^{\mathrm{J}}$-x. Zhao ${ }^{\mathrm{e}}$, \\ C.S.M. Turney ${ }^{a}$, K. Fifield $^{\mathrm{f}}{ }$ H. Allen ${ }^{\mathrm{g}}$, R.P. Soejono ${ }^{\mathrm{b}}$ \\ ${ }^{a}$ GeoQuEST Research Centre, School of Earth and Environmental Sciences, University of Wollongong, Wollongong, NSW 2522, Australia \\ ${ }^{\mathrm{b}}$ Indonesian Research and Development Centre for Archaeology, Jl. Raya Condet Pejaten No. 4, Jakarta 12001, Indonesia \\ ${ }^{\mathrm{c}}$ School of Humanities, University of New England, Armidale, NSW 2351, Australia \\ ${ }^{\mathrm{d}}$ Balai Arkeologi, Jogyakarta, Indonesia \\ ${ }^{\mathrm{e}}$ Radiogenic Isotope Laboratory, Centre for Microscopy and Microanalysis, University of Queensland, Queensland 4072, Australia \\ ${ }^{\mathrm{f}}$ Department of Nuclear Physics, Research School of Physical Sciences and Engineering, Australian National University, \\ Canberra, ACT 0200, Australia \\ ${ }^{\mathrm{g}}$ Department of Anthropology, University of Auckland, New Zealand
}

Received 10 September 2007; received in revised form 14 November 2007; accepted 27 November 2007

\begin{abstract}
Song Gupuh, a partially collapsed cave in the Gunung Sewu Limestones of East Java, Indonesia, contains over $16 \mathrm{~m}$ of deposits with a faunal sequence spanning some $70 \mathrm{ka}$. Major changes in the range of animals represented show the impact of climate change and humans. The Terminal Pleistocene and Early Holocene was a period of maximum biodiversity. Human use of Song Gupuh and other cave sites in the region also intensified significantly from ca. $12 \mathrm{ka}$, together with a new focus on exploitation of small-bodied species (macaque monkeys and molluscs), the first evidence for import of resources from the coast, and use of bone and shell tools. Human activity, especially after the onset of the Neolithic around $2.6 \mathrm{ka}$, subsequently contributed to a progressive loss of many species from the area, including tapir, elephant, Malayan bear, rhino and tiger, and this extinction process is continuing. We conclude by discussing the biogeographical significance of Song Gupuh in the context of other sites in Java (e.g. Punung, Wajak) and further afield (e.g. Liang Bua).
\end{abstract}

(C) 2007 Elsevier Ltd. All rights reserved.

Keywords: Java; Archaeology; Excavation; Cave; Stone artefacts; Fauna; Palaeoenvironment; Biogeography

\section{Introduction}

The continental island of Java has one of the richest and most diverse fossil faunal sequences in the world. This diversity reflects the migration of new species from mainland Asia during periods of glacially lowered sea level, and in situ (endemic) evolution of the fauna during the intervening periods when Java was an island. Major gaps in our understanding

\footnotetext{
* Corresponding author. GeoQuEST Research Centre, School of Earth and Environmental Sciences, University of Wollongong, Northfields Avenue, Wollongong, NSW 2522, Australia. Tel.: +61 24221 3189; fax: +61 242214250 .

E-mail address: mikem@uow.edu.au (M.J. Morwood).
}

of this faunal succession persist, however, because of uncertainties about the age of key deposits, their taphonomy and environmental context, and the exact provenance of finds. The faunal sequence at Song Gupuh in East Java helps fill the 70-ka gap from the beginning of the last glacial period to the present.

Song Gupuh, meaning 'Flee Cave' in the local Javanese language, is a partially collapsed limestone cave on the east margin of the Gunung Sewu (Thousand Mountains) region near the provincial capital, Punung. It is located at the base of a limestone hill, $2 \mathrm{~km}$ north of the Baksoko/Kladen River and $10 \mathrm{~km}$ from the south coast at an altitude of $339 \mathrm{~m}$ above sea level (Fig. 1). The limestones in this karst region appear to 

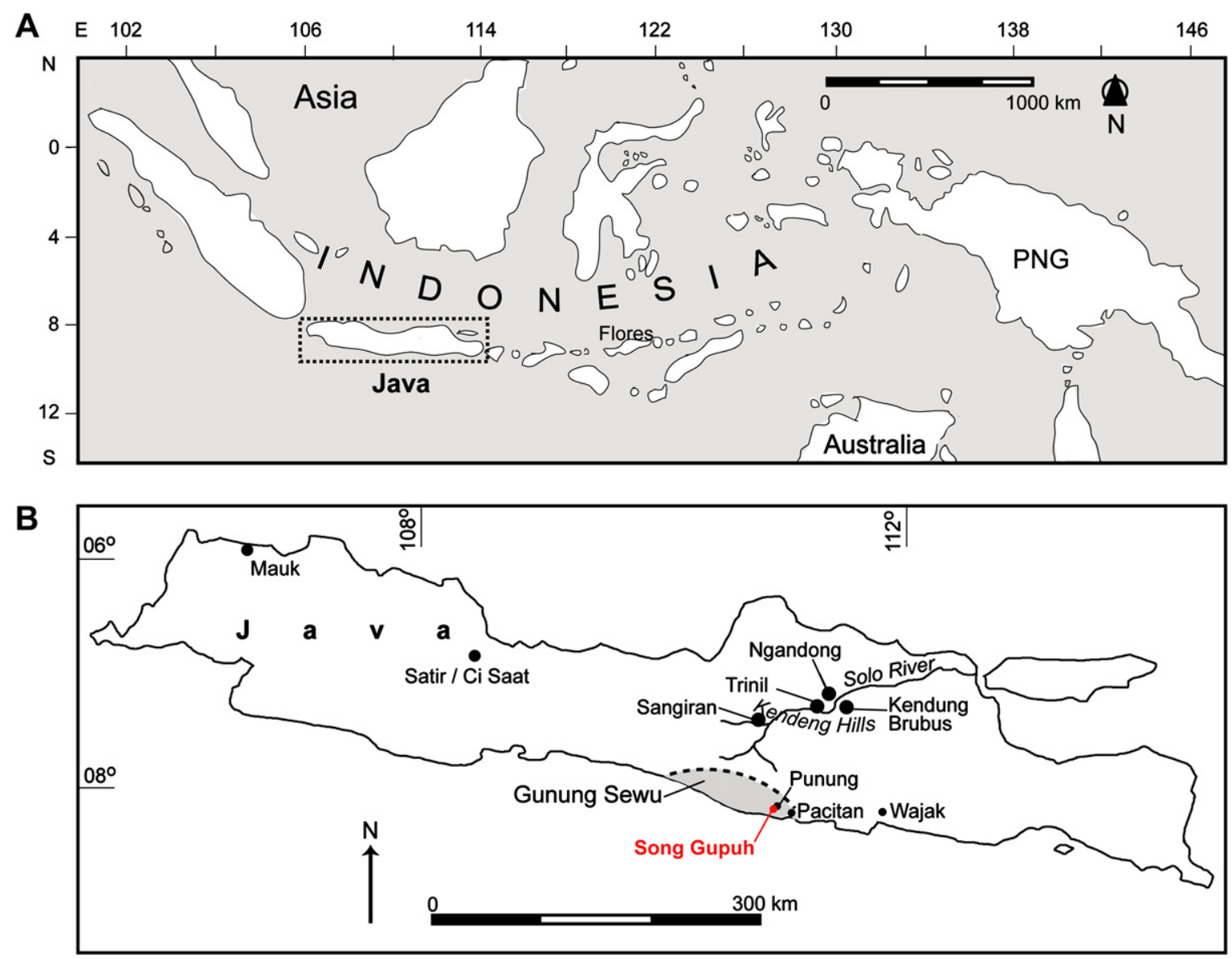

Fig. 1. General location of Java, Gunung Sewu and Song Gupuh.

weather relatively rapidly and have formed a landscape characterised by numerous rounded hills riddled with caves, sinkholes and dolines.

Archaeological and palaeontological investigation in the region began in 1936 with the work of von Koenigswald, who collected large artefacts along the Basoko River (the Pacitanian Industry) and excavated at two fossiliferous breccia sites, Punung I and II, which yielded the type assemblage for the Punung Fauna, a distinct unit in the proposed biostratigraphic sequence for Java (e.g. Von Koenigswald, 1939; De Vos, 1983; Van den Bergh et al., 2001). Other cave sites previously excavated in the Gunung Sewu include Song Agung, Song Terus, Song Keplek, Song Tritis, Gua Braholo and Song Tabuhan Many open Neolithic sites characterised by pottery and adze flaking floors also occur, while immediately to the north, in the Solo River depression, lie many of the classic Indonesian Homo erectus and associated fossil fauna sites, such as Sangiran, Trinil, Ngandong and Sambungmacan (e.g. Ithara et al., 1994; Semah et al., 1998) (Fig. 1).

Since the Gunung Sewu had emerged from the sea by the Middle Pleistocene (Simandjuntak and Barber, 1996), limestone caves in the region with deeply stratified deposits or breccias could provide evidence on long term changes in fauna, including the life and times of $H$. erectus, as well as subsequent events, such as the arrival of modern humans
(Westaway et al., 2007a). More recent parts of the cultural sequence also document the process of economic intensification in the early Holocene; the appearance of new technologies, such as agriculture, ground stone adzes, pottery and metal; and the impacts of human population growth (e.g. Simanjuntak and Prasetyo, 2004).

\section{The site}

Song Gupuh is $50 \mathrm{~m}$ long, $13 \mathrm{~m}$ wide, $13 \mathrm{~m}$ high at the entrance, faces north and is situated on the south side of a karst cone (Figs. 2, 3). It was formed as an underground cavern through dissolution, which was then exposed by collapse processes along a central east-west axis. The margins of the original cave are marked by the present-day shelters at the base of the scarps flanking two large cone karst features on either side of the road to Punung. Song Gupuh would have comprised the southern edge of the former cave.

During a later stage in the evolution of the cave, it would have acted as a sink receiving sediment rich slopewash from interconnected source caves found close by, including Song Gupuh Kidul, Song Gunung and Song Citril. However, there is a history of recent disturbance at the site. Before clearance of the above hill slope for cultivation, deposits were at least $60 \mathrm{~cm}$ higher at the east end. Scouring of the uppermost 


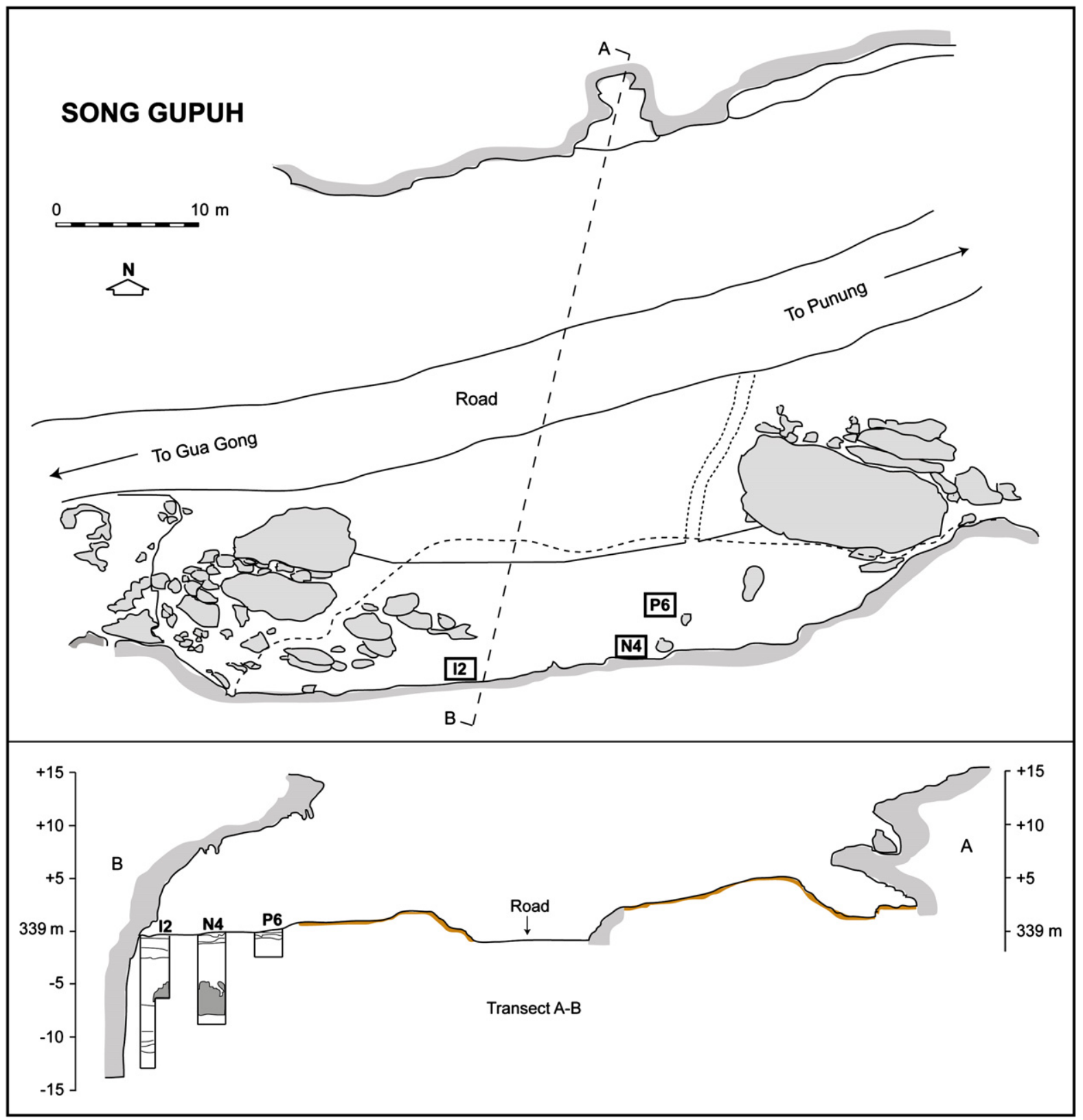

Fig. 2. Plan of Song Gupuh showing the three $2 \times 2 \mathrm{~m}$ excavated sectors.

deposits then occurred. In 1960, the surface of the shelter floor was levelled to enable local people to hold meetings and performances in the shelter, and earth was moved from the higher east end of the shelter to the west. In 1970, the first road was constructed running east-west through the saddle fronting the shelter. This road was positioned very close to the site, and passed under the dripline at one point. Layers of rubble evident at the top of some excavated sectors resulted from this road construction.

Professor R.P. Soejono (Indonesian Centre of Archaeology) and Associate Professor Harry Allen (University of Auckland) excavated five $2 \times 2 \mathrm{~m}$ sectors (I2, K3, K5, N4, P6) at Song Gupuh in 1995, 1997, 1999 and 2000 (Sutikna, 2001). They reached a maximum depth of $3.7 \mathrm{~m}$ and obtained an associated radiocarbon date of $7570 \pm 170 \mathrm{BP}$. The excavations yielded artefacts of stone, bone, teeth, wood, shell and a single item of metal (a gold ring); pottery (fragments and completed pots); burials containing grave goods, such as pots, beads and stone adzes; hearths; faunal remains; and plant remains, including charcoal and seeds. The morphology of the shelter and its surrounds, however, indicated that the deposits were likely to be much deeper, with older occupation levels, artefacts and faunal evidence. With this potential in mind we excavated at Song Gupuh from 16th February to 31st March 2004 and from 9th February to 25th March 2005.

\subsection{Field procedures}

We selected three of the previously excavated $2 \times 2 \mathrm{~m}$ sectors (P6, N4 and I2). The aim was to continue the 


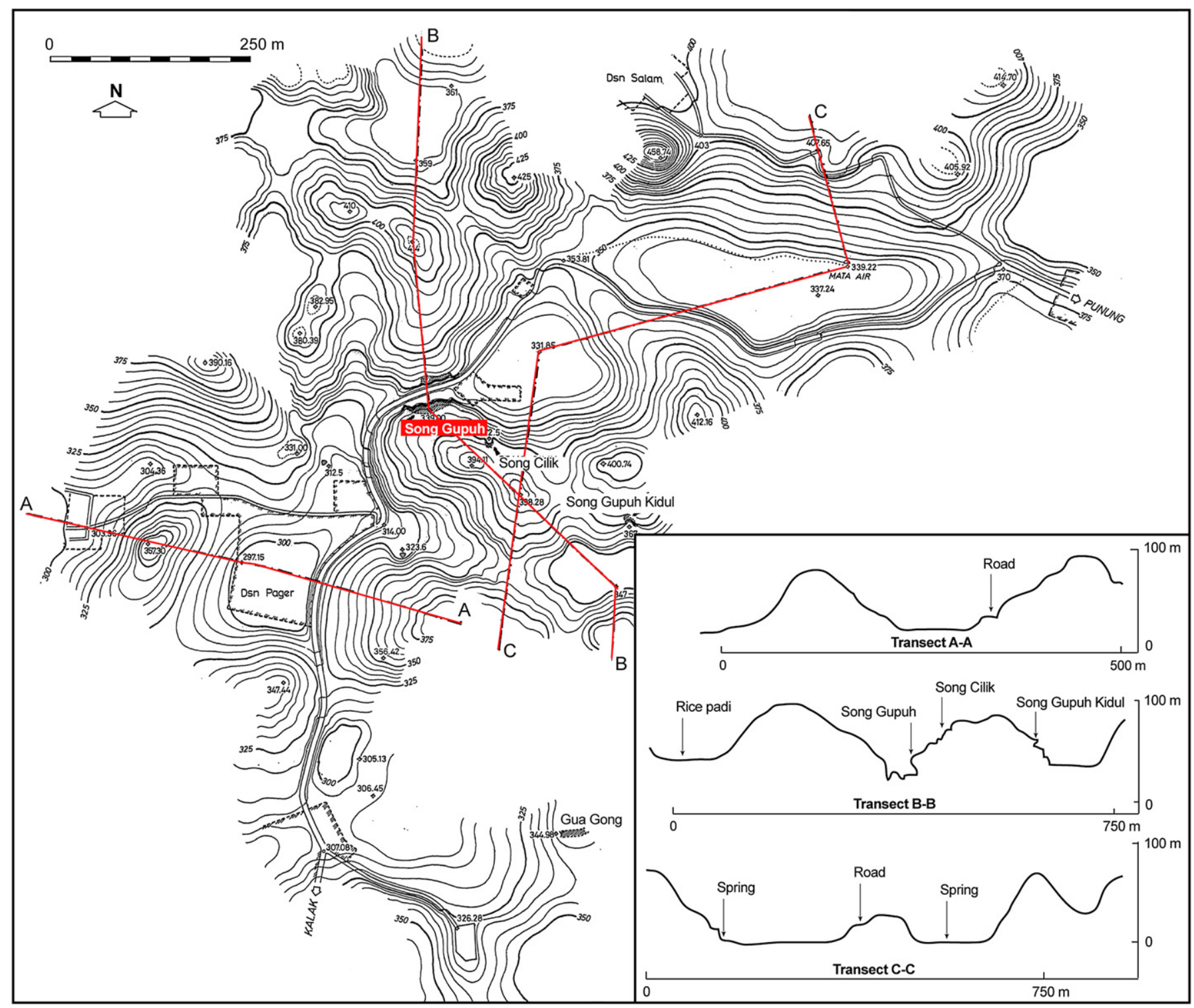

Fig. 3. Contour map of the areas around Song Gupuh showing cross-sections of local topography.

excavations in at least one of these to bedrock, and to date the entire cultural and faunal sequence. For each selected sector, backfill was removed to expose in situ deposits. We then used timber shoring of the baulks for safety as the excavations deepened. We also plotted and bagged artefacts, faunal remains, seeds and charcoal found by the excavators; dry sieved excavated deposits with a $2 \mathrm{~mm}$ mesh; and took bulk samples of stratigraphic units for sediment, pollen and phytolith analyses. Westaway (2006) also took samples for luminescence and uranium-series dating of excavated materials, and used speleothems from other caves in the vicinity to reconstruct a local palaeo-climatic history spanning much of the last $100 \mathrm{ka}$.

\subsection{Dating procedures}

Ages of the Song Gupuh deposits were determined with the thermoluminescence (TL), optically stimulated luminescence
(OSL), thermal ionisation mass spectrometry (TIMS) uraniumseries and radiocarbon dating methods. U-series dating was applied to in situ flowstone deposits that were precipitated onto collapse material lying on the floor of the cave. The results of these samples will provide maximum and minimum age constraints for the timing of sediment deposition above and below the collapse material using analytical procedures described elsewhere (Zhao et al., 2001).

We used the same dual aliquot (DAP) red TL dating procedure described in detail in Westaway and Roberts (2006) to estimate the time elapsed since sand-sized quartz grains in the sediments were last exposed to sunlight. The red TL result should be conservatively viewed as a maximum age, to allow for the possibility that not all of the grains had been sufficiently bleached at deposition. We also measured the linearly modulated OSL signals of individual quartz grains to isolate the most light-sensitive OSL component for dating. However, the fast-to-bleach component could not be detected in the OSL 


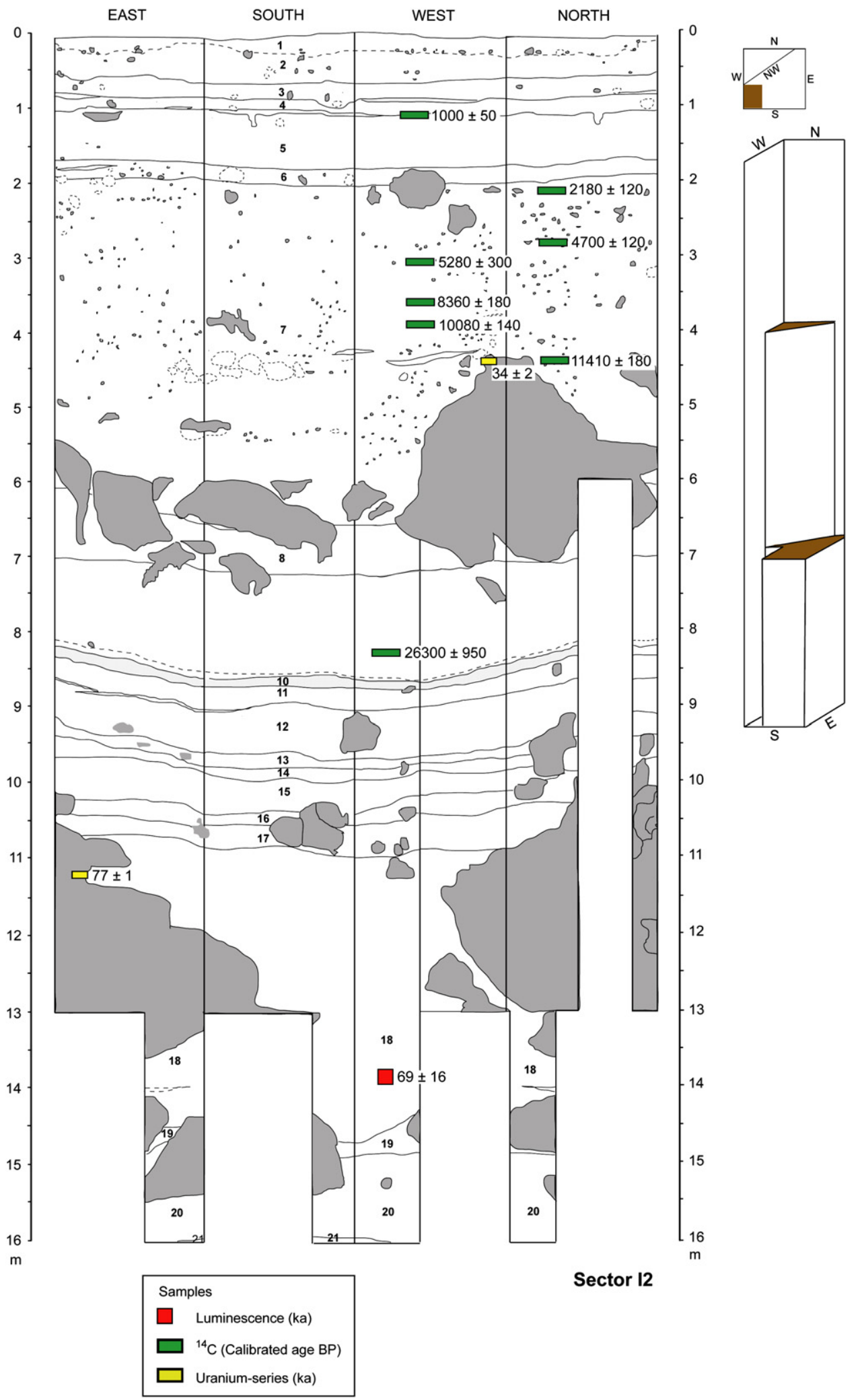


Table 1a

A chronology for the sectors in Song Gupuh: AMS radiocarbon dating of charcoal from Sectors I2, N4 and P6

\begin{tabular}{|c|c|c|c|c|c|}
\hline Sector & Sample & Depth $(\mathrm{m}) /$ spit & Significance & $\begin{array}{l}\text { Radiocarbon } \\
\text { age (BP) }\end{array}$ & $\begin{array}{l}\text { Calibrated } \\
\text { age (BP) }\end{array}$ \\
\hline \multirow[t]{8}{*}{$\mathrm{I} 2$} & Wk 14647 & $1.1-1.2 / 12$ & Associated with a change in the pottery sequence & $1130 \pm 41$ & $1000 \pm 50$ \\
\hline & Wk 14648 & $2.2-2.3 / 23$ & $\begin{array}{l}\text { From the spit above the first evidence for the Neolithic, } \\
\text { as marked by appearance of pottery and ground adzes }\end{array}$ & $2183 \pm 39$ & $2180 \pm 120$ \\
\hline & Wk 8694 & $2.85 / 29$ & - & $4180 \pm 60$ & $4700 \pm 120$ \\
\hline & Wk 8692 & $3.05-3.15 / 31$ & - & $4620 \pm 200$ & $5280 \pm 300$ \\
\hline & Wk 8963 & $3.65 / 37$ & - & $7570 \pm 170$ & $8360 \pm 180$ \\
\hline & Wk 14649 & $3.9-4.0 / 40$ & $\begin{array}{l}\text { The uppermost level for a concentration of } \\
\text { artefacts and faunal remains }\end{array}$ & $8996 \pm 59$ & $10080 \pm 140$ \\
\hline & Wk 14650 & $4.4-4.5 / 45$ & $\begin{array}{l}\text { The lowermost level for a concentration of } \\
\text { artefacts and faunal remains }\end{array}$ & $9961 \pm 60$ & $11410 \pm 180$ \\
\hline & ANUA-32719 & $8.35-8.45 / 84$ & Just above a grey tuffaceous silt & $22,750 \pm 475$ & $26,300 \pm 950$ \\
\hline \multirow[t]{3}{*}{ N4 } & Wk 18545 & $1.00-1.05 / 11$ & - & $599 \pm 36$ & $580 \pm 50$ \\
\hline & Wk 18546 & $1.65-1.70 / 24$ & - & $4946 \pm 35$ & $5630 \pm 30$ \\
\hline & Wk 15327 & $2.65-2.70 / 44$ & - & $7538 \pm 67$ & $8300 \pm 90$ \\
\hline \multirow[t]{3}{*}{ P6 } & Wk 18547 & $85-90 / 11$ & & $5109 \pm 36$ & $5820 \pm 70$ \\
\hline & Wk 15329 & $1.55-1.69 / 25$ & Layer 3 & $5675 \pm 57$ & $6400 \pm 80$ \\
\hline & Wk 15330 & $2.45-2.50 / 43$ & Layer 3, near the base of the excavated deposits & $7344 \pm 57$ & $8110 \pm 60$ \\
\hline
\end{tabular}

Sample ANUA-32719 was prepared using ABOX pretreatment and step-combusted at the University of Wollongong, as described by Bird et al. (1999) and Turney et al. (2001). The result from this sample represents a minimum age as it came from the lowest temperature fraction. For the other determinations, radiocarbon dating was undertaken on hand-picked charcoal at Waikato Laboratory, New Zealand, using conventional radiocarbon techniques.

emissions, so the age obtained from the less light-sensitive OSL signals should also be regarded as a maximum age for sediment deposition.

Radiocarbon dating was undertaken on hand-picked charcoal, while one sample was first prepared using ABOX pretreatment (ANUA-32179) and step-combusted, as described by Bird et al. (1999) and Turney et al. (2001).

\subsection{Sector $I 2$}

We excavated this sector by $10 \mathrm{~cm}$ spits and stratigraphic units to a depth of $16 \mathrm{~m}$ without reaching bedrock. However, in situ stalagmites indicated that bedrock was probably close (Fig. 4). Eight charcoal samples from I2 yielded radiocarbon ages ranging from 1 to $22 \mathrm{ka} \mathrm{BP}$ (Table 1a). Samples were calibrated assuming an interhemispheric offset of $40 \pm 13$ years (Hogg et al., 2002). Ages $<20$ ka BP were calibrated against the IntCal04 dataset (Reimer et al., 2004); the sample $>20 \mathrm{ka}$ BP was calibrated using the Cariaco Basin dataset
(Hughen et al., 2006). Two U-series determinations from in situ flowstones provide maximum ages for sediments at 4 and $11 \mathrm{~m}$ depth (Table 1c). In addition, a red thermoluminescence age was obtained for sandy silt at $\sim 14 \mathrm{~m}$ depth, and the same sample also yielded a single-grain OSL result (Table 1b).

\subsection{Sector N4}

We excavated this sector by 10 and $5 \mathrm{~cm}$ spits, as well as stratigraphic units, to a depth of $12 \mathrm{~m}$, where massive slabs of rockfall prevented further work (Fig. S1). Charcoal samples from Sector N4 yielded radiocarbon ages ranging from 500 years BP to $7 \mathrm{ka}$ BP (Table 1a). In addition, maximum ages for sediment deposition and flowstone precipitation were obtained from the base of Sector N4 using U-series techniques applied to an in situ flowstone (Table 1c) and red TL techniques applied to the basal sedimentary unit, respectively (Table 1b).

Fig. 4. Stratigraphic layers in Sector I2. Layer 1a: recently disturbed earth, yellowish-brown (10YA 5/3), depth 0-20 cm, fill from levelling of the surface in 1960, pH 6.5. Layer 1b: disturbed, dark brown, depth $20-35 \mathrm{~cm}$, fill from levelling of the surface in 1960, pH 6.5. Layer 2: dark brown sandy silt with some soil development (10YR 2/2), depth 35-75 cm, contains artefacts of the historical period, such as Chinese ceramics, pH 6.5, and many highly weathered small clasts. Layer 3: yellowish-brown silt (10YR 5/4), depth 75-100 cm, pH 7. Layer 4: dark brown clayey silt (7.5YR 4/6), depth 100-110 cm. Layer 5: dark, yellowishbrown clayey silt (10YR 3/4), 110-180 cm, pH 7. Layer 6: dark brown (7.5YR3/4) sandy silt, 180-200 cm, pH 7.5. Layer 7: dark brown (7.5YR3/4) clayey silt, 200-600, pH 7.5 containing many fragments of bone, from 200-261 cm depth, there was limestone rockfall. The earliest evidence for the Neolithic (e.g. pottery, adze blanks) occurs immediately above this rockfall. Layer 8: massive rock fall, 600-740 cm. Layer 9: dark brown (7.5YR3/4) clayey silt, $740-860 \mathrm{~cm}$, pH 8.5 . Layer 10: a light brownish grey (10YR6/2) silt (tephra), 860-870 cm, pH 7.5, thought to be an airfall deposit. Dips towards the south and contains a loaded lower bedding contact indicating final deposition within a small amount of standing water. Layer 11: dark reddish brown (5YR3/4) silty clay, 870-890 cm, pH 9, horizontally bedded. Layer 12: very dark brown (10YR2/2) silty clay, $890-960 \mathrm{~cm}, \mathrm{pH} 8.5$, dips to the south. Layer 13: yellowish brown (10YR 5/4) silty clay, $960-980 \mathrm{~cm}$, dips to the south with a pH of 8.5. Layer 14: silty clay (with a finer silt texture), $980-990 \mathrm{~cm}$, dips to the south. Layer 15 : light yellowish brown (10YR 6/4) clayey silt, 990-1025 cm dipping with a gentler angle to the south, pH 9. Layer 16: silty clay, $1025-1050 \mathrm{~cm}$ dipping at a more gentle angle. Layer 17: silty clay, 1050-1080 cm dipping at a more gentle angle. Layer 18: brownish yellow (10YR 6/6) sandy silt, 1080-1200 cm, pH 7.5. Contains flowstone precipitated over large blocks of limestone. Flowstone sampled at $11.20 \mathrm{~m}$ for U-series dating (SPJ16). Layer 19: sandy silt. 
Table $1 b$

Luminescence dating of sediment from I2 and N4

\begin{tabular}{|c|c|c|c|c|c|c|}
\hline $\begin{array}{l}\text { Sample } \\
\text { code/sector }\end{array}$ & $\begin{array}{l}\text { Sample } \\
\text { depth (m)/layer }\end{array}$ & Dating technique & $\begin{array}{l}\text { Grain } \\
\text { diameter }(\mu \mathrm{m})\end{array}$ & $\begin{array}{l}\text { Total dose } \\
\text { rate }\left(\mathrm{Gy} \mathrm{ka}^{-1}\right)^{\mathrm{a}}\end{array}$ & $\begin{array}{l}\text { Equivalent } \\
\operatorname{dose}^{\mathrm{a}}(\mathrm{Gy})\end{array}$ & $\begin{array}{l}\text { Optical and } \\
\text { TL age }^{\mathrm{a}}(\mathrm{ka})\end{array}$ \\
\hline \multirow[t]{2}{*}{ SGI2-7/I2 } & 13.8-14.0/L19 & Red TL & $125-212$ & $1.29 \pm 0.11$ & $88 \pm 19$ & $69 \pm 16^{\mathrm{b}}$ \\
\hline & & Single-grain OSL & $125-212$ & $1.25 \pm 0.10$ & $124 \pm 16$ & $99^{+15} /-\infty$ \\
\hline SGN4-6/N4 & 11.1-11.3/L5 & Single-grain OSL & $125-212$ & $1.06 \pm 0.04$ & $65 \pm 22$ & $61^{+15} /-21$ \\
\hline
\end{tabular}

${ }^{a}$ Uncertainties at $68 \%$ confidence interval.

b Determined from the light-sensitive red TL signal.

Table 1c

TIMS uranium-series dating of flowstones from 12 and N4

\begin{tabular}{|c|c|c|c|c|c|c|c|c|c|}
\hline $\begin{array}{l}\text { Sample } \\
\text { code }\end{array}$ & $\begin{array}{l}\text { Sector/sample } \\
\text { depth }(\mathrm{m})\end{array}$ & $\begin{array}{l}{ }^{238} \mathrm{U} \\
(\mathrm{ppm})\end{array}$ & $\begin{array}{l}{ }^{232} \mathrm{Th} \\
(\mathrm{ppb})\end{array}$ & $\begin{array}{l}{ }^{230} \mathrm{Th} /{ }^{232} \mathrm{Th} \\
\text { activity ratio }\end{array}$ & $\begin{array}{l}{ }^{234} \mathrm{U} /{ }^{238} \mathrm{U} \\
\text { activity ratio }\end{array}$ & $\begin{array}{l}{ }^{230} \mathrm{Th} /{ }^{238} \mathrm{U} \\
\text { activity ratio }\end{array}$ & $\begin{array}{l}\text { Corrected } \\
\text { initial }{ }^{234} \mathrm{U} /{ }^{238} \mathrm{U} \\
\text { activity ratio }\end{array}$ & $\begin{array}{l}\text { Uncorrected } \\
\text { age }(\mathrm{ka})^{\mathrm{a}}\end{array}$ & $\begin{array}{l}\text { Corrected } \\
\text { age }(\mathrm{ka})^{\mathrm{b}}\end{array}$ \\
\hline SPJ14 & $\mathrm{I} 2 / 4.48$ & 0.033 & 4.159 & 7.154 & $10.394 \pm 0.003$ & $0.302 \pm 0.003$ & $1.045 \pm 0.003$ & $37.18 \pm 0.42$ & $33.50 \pm 1.89$ \\
\hline SPJ16 & $\mathrm{I} 2 / 11.20$ & 0.699 & 6.525 & 170.646 & $1.029 \pm 0.003$ & $0.525 \pm 0.002$ & $1.036 \pm 0.004$ & $77.27 \pm 0.64$ & $77.01 \pm 0.65$ \\
\hline SPJ18 & N4/10.86 & 0.218 & 97.301 & 5.300 & $1.045 \pm 0.002$ & $0.780 \pm 0.023$ & $1.075 \pm 0.007$ & $146.81 \pm 9.14$ & $133.67 \pm 10.99^{\mathrm{b}}$ \\
\hline
\end{tabular}

${ }^{\text {a }}$ Uncertainties at $95 \%$ confidence interval.

b In situ flowstone near the base of the sector is impure and therefore, only provides a maximum age for deposits in this section of the site.

\subsection{Sector P6}

We excavated this sector by 10 and $5 \mathrm{~cm}$ spits, as well as stratigraphic units, to a maximum depth of $2.75 \mathrm{~m}$, where a fallen slab of limestone over the entire sector blocked further work (Fig. S2). All of the cultural deposits here are of preNeolithic age as the sequence has been truncated by road construction. Charcoal samples from P6 yielded radiocarbon ages ranging from 5 to $7 \mathrm{ka}$ BP (Table 1a).

\subsection{Findings}

The timing and pattern of change were similar in all excavated areas. Sector I2, however, yielded the longest and most complete artefact and faunal assemblage and is the main focus of this paper, with selective use of information from other sectors.

\subsection{Stone artefacts}

We excavated 7284 stone artefacts from Sector I2 (Table 2b). The deepest were found $12.5 \mathrm{~m}$ below the present-day shelter floor with an age of around 50,000 BP inferred on the basis of available luminescence and radiocarbon results. Despite variation in artefact densities, a single technological tradition is evident in the pre-Neolithic deposits at the site, characterised by emphasis on use of chert, silcrete and other siliceous materials of variable quality and colour to produce flakes of variable size and thickness, usually from multiplatform cores. Most stone tools, identified on the basis of use wear and retouch, were expediently made on flakes, while associated cores tended to be large and not significantly reduced.

The earliest cultural deposits had relatively few artefacts with little evidence for in situ flaking and a relatively high proportion of utilised artefacts, including two large flake choppers made on thick chert flakes with heavily step-fractured dorsal surfaces that were almost certainly made offsite. Higher in the sequence between 12 and $10 \mathrm{ka} \mathrm{BP}$, however, stone artefact densities, deposition rates and other measures of occupational intensity increased significantly, together with evidence for intensive, onsite knapping. Spits 46-39, for instance, contained flaking floors with multiplatform, single platform and radial cores, as well as clusters of flaking waste and andesite hammerstones (Fig. 5). Significantly, no grindstones, pounders or other artefacts associated with processing of plant foods were found, despite the recovery of five canarium seeds.

Around $2.6 \mathrm{ka} \mathrm{BP}$, evidence for pottery use and stone adze manufacture appears abruptly in the sequence (Table 2). Knapping was now mainly concerned with the mass production of rectangular-sectioned adze blanks (Fig. 6), and in Spits 2421 adze-flaking floors were evident. These hallmarks of the Neolithic coincided with other changes in stone artefact production. In particular, there was a change in raw material use with knappers consistently selecting better quality, more homogeneous materials, with a preference for pale brown chert. Characteristically, large flake blanks were struck offsite and brought to the shelter for shaping and thinning by indirect percussion. As a result, Neolithic occupation levels at Song Gupuh are characterised by relatively high artefact densities, but low core to flake and tool to waste ratios. The degree to which the Neolithic is represented at Song Gupuh is unusual for rockshelter and cave sites in the region, where evidence for such occupation is most evident in extensive concentrations of adze flaking waste and pottery at open quarry sites.

\subsection{Faunal remains}

The deepest faunal remains at Song Gupuh were found $14.7 \mathrm{~m}$ below the present-day shelter floor with an inferred age of around 70,000, but the deepest hominin skeletal evidencethe skull of a modern human child—only dated to $\sim 11,500 \mathrm{BP}$. 


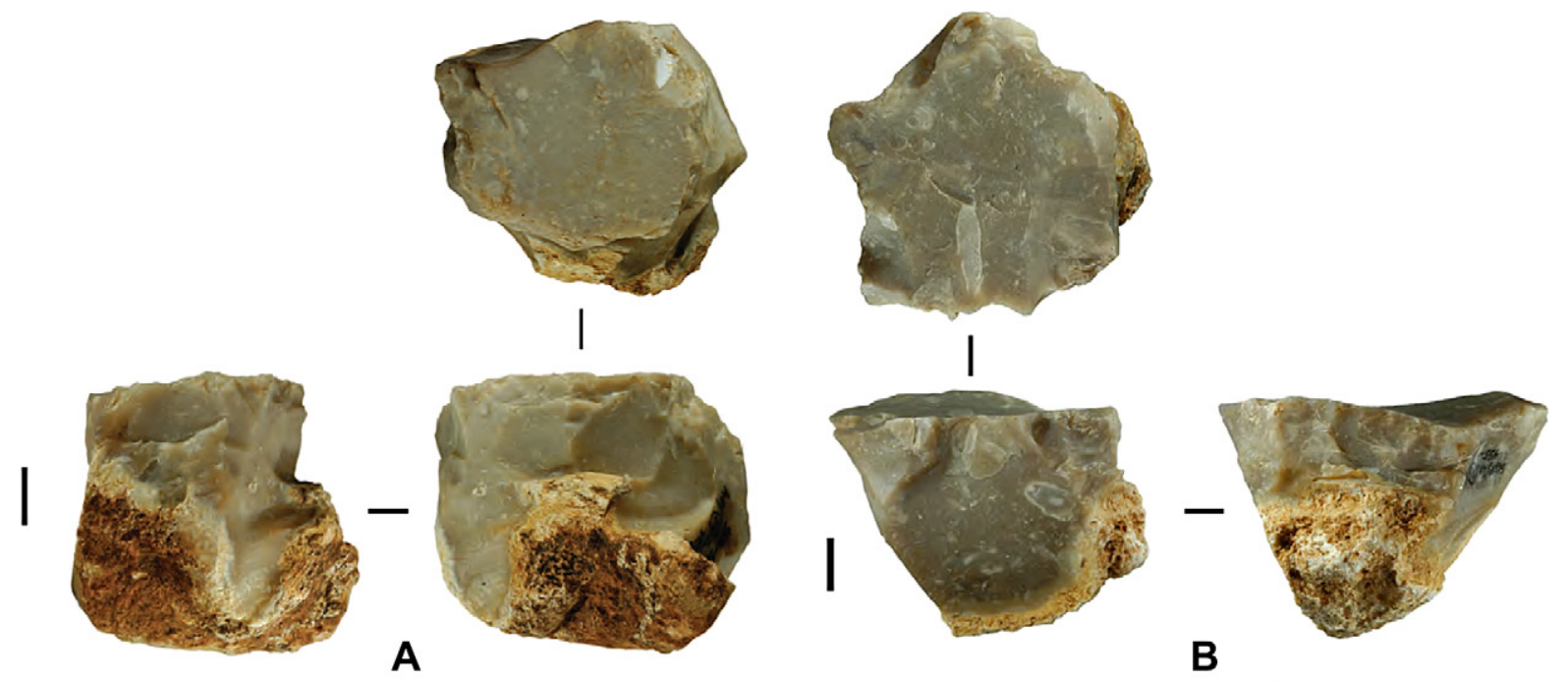

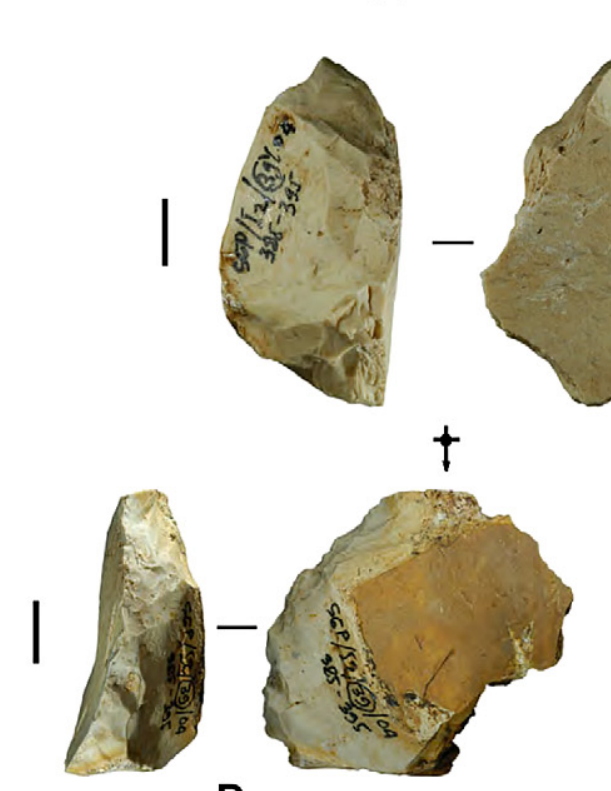

D

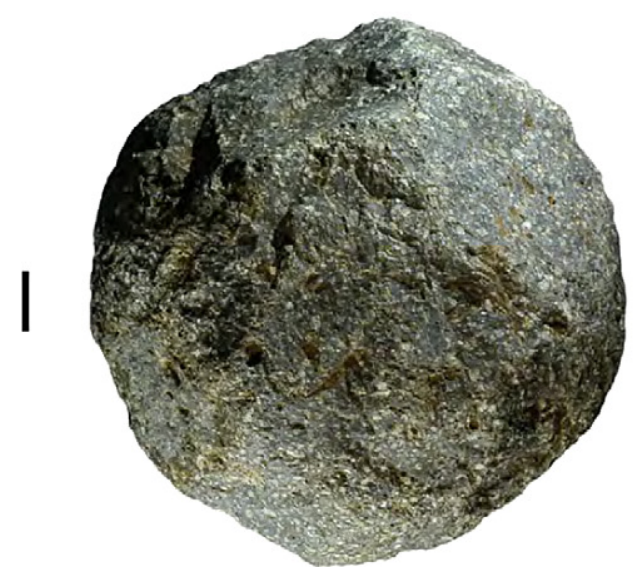

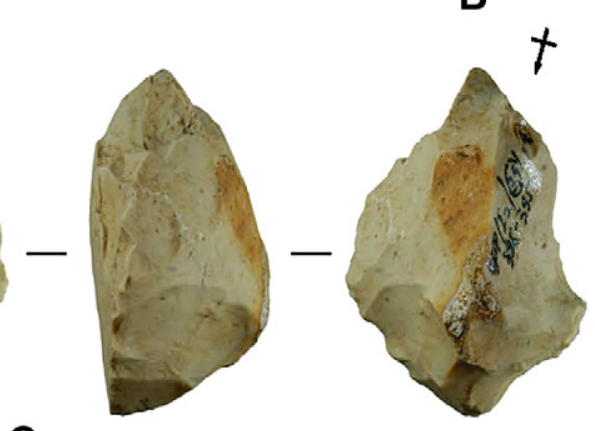

C

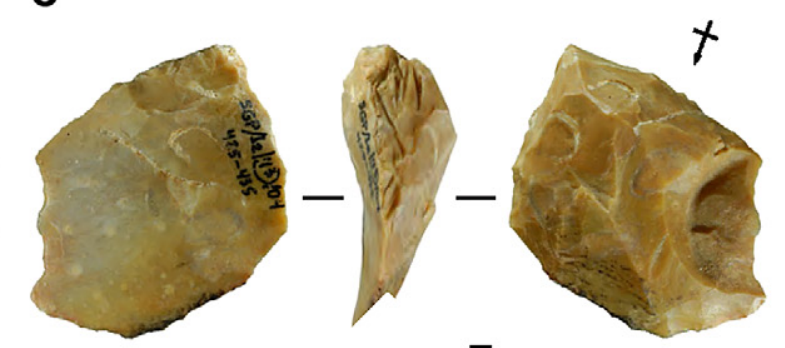

E

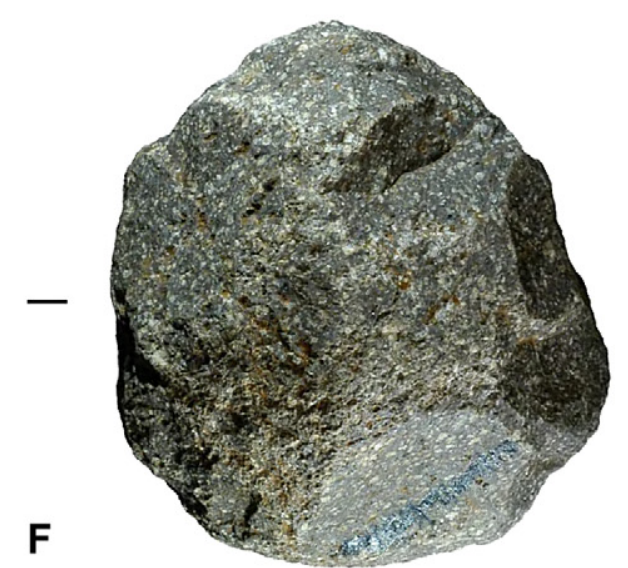

Fig. 5. Early Holocene artefacts from Song Gupuh. (A,B) Chert single-platform cores. (C-E) Chert retouched flakes. (F) Andesite hammerstone. Scale bars (vertical thickened lines) $10 \mathrm{~mm}$ (photo: M.W. Moore). 

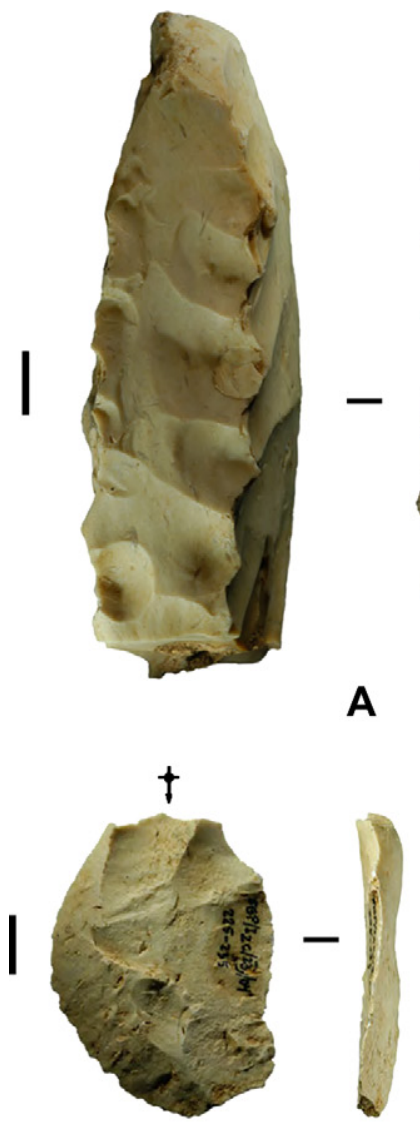

C
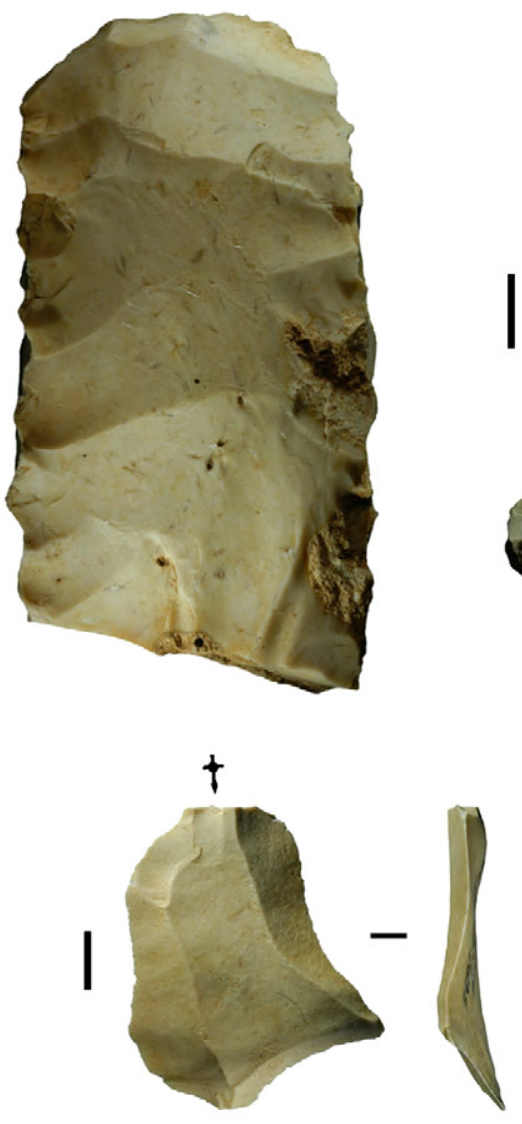

D
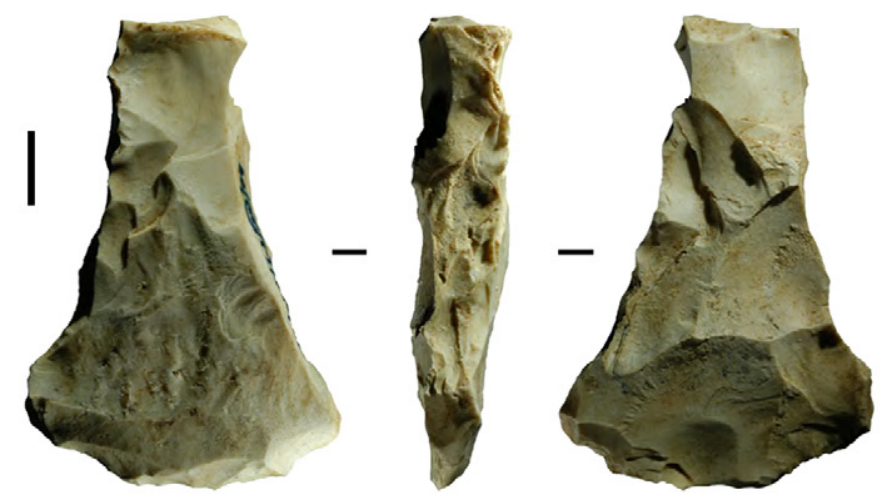

B

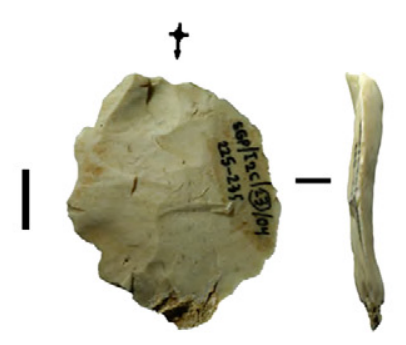

E

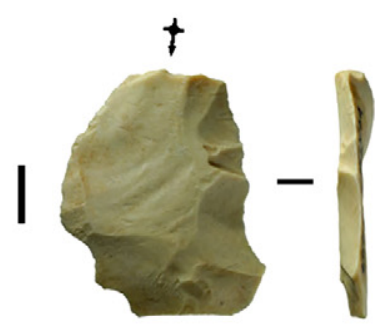

F

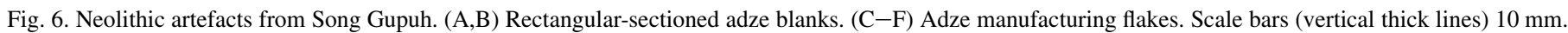

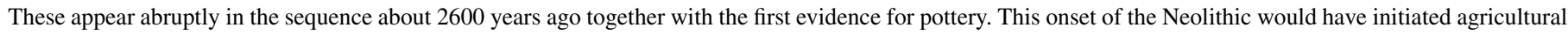
clearance and greater human impacts on local fauna (photo: M.W. Moore).

Large animals represented in order of frequency comprise macaque (Macaca fascicularis), deer (Rusa sp., Muntiacus muntjac, Tragulus javanicus), bovid (Bos sp., Bubalus sp.), pig (Sus scrofa, Suidae indet.), rhino (Rhinoceros sondaicus), Asian elephant (Elephas maximus), sun bear (Helarctos malayanus) and tapir (Tapirus indicus). Their distribution in the Sector I2 sequence clearly shows the impacts of environmental change, plus increased human presence and preference from the terminal Pleistocene (Table 2a). For instance, the earliest fauna represented at the site is dominated by a few species-deer, pig and bovid-suggesting open, dry conditions generally, but with some closed forest and thick understorey, as required by tapir. These inferred climate conditions agree with stalagmite records from East Java, which display a gradual shift to drier conditions over this period (Westaway et al., 2007a). The percussive breakage patterns on some of the deer and bovid long bones indicate that humans were at least partially responsible for the earliest bone accumulation at the site.

With the onset of warmer and wetter conditions, thicker soils and increased bio-productivity between 17 and $10 \mathrm{ka} \mathrm{BP}$ (Westaway et al., 2007a,b), the number and range of animals represented in the site increased significantly; deer, pig, bovids, bear, elephant, rhino and tapir are all evident, associated with modern human skeletal remains. The most spectacular change, however, is a huge increase in macaque frequency. The same trend occurs in other excavated sites in the region, such as Gua Braholo and Song Keplek (Simanjuntak and Prasetyo, 2004), indicating that human hunters were now selectively targeting monkeys.

Other evidence for more intensive use of smaller-bodied faunal resources from a wider range of habitats in the terminal Pleistocene is seen in the first use of molluscs. Some, such as land snails, may occur onsite naturally, with isolated examples in the Pleistocene deposits. Systematic use of molluscs began around $12 \mathrm{ka}$, however, indicating an expansion of resource base and the first transport of resources from the coast - the source of most shellfish. The change is only sparsely represented in Sector I2, which is predominantly a stone working area, but is very clear in Sector N4, where the first intensive human exploitation of molluscs and macaques coincided (Table S1).

In addition, more intensive use of faunal resources generally is seen in the associated appearance of shell and bone artefacts at Song Gupuh. Similar bone points occur at the nearby site of Gua Braholo from ca. $12 \mathrm{ka}$ (Prasetyo, 2004). They continue through the Neolithic and into the last 500 years. Only one shell scraper and 11 bone artefacts were found in Sector I2, but the more 'domestic' Sectors N4 and 
Table 2a

Faunal remains excavated from Sector I2, Song Gupuh (NISP)

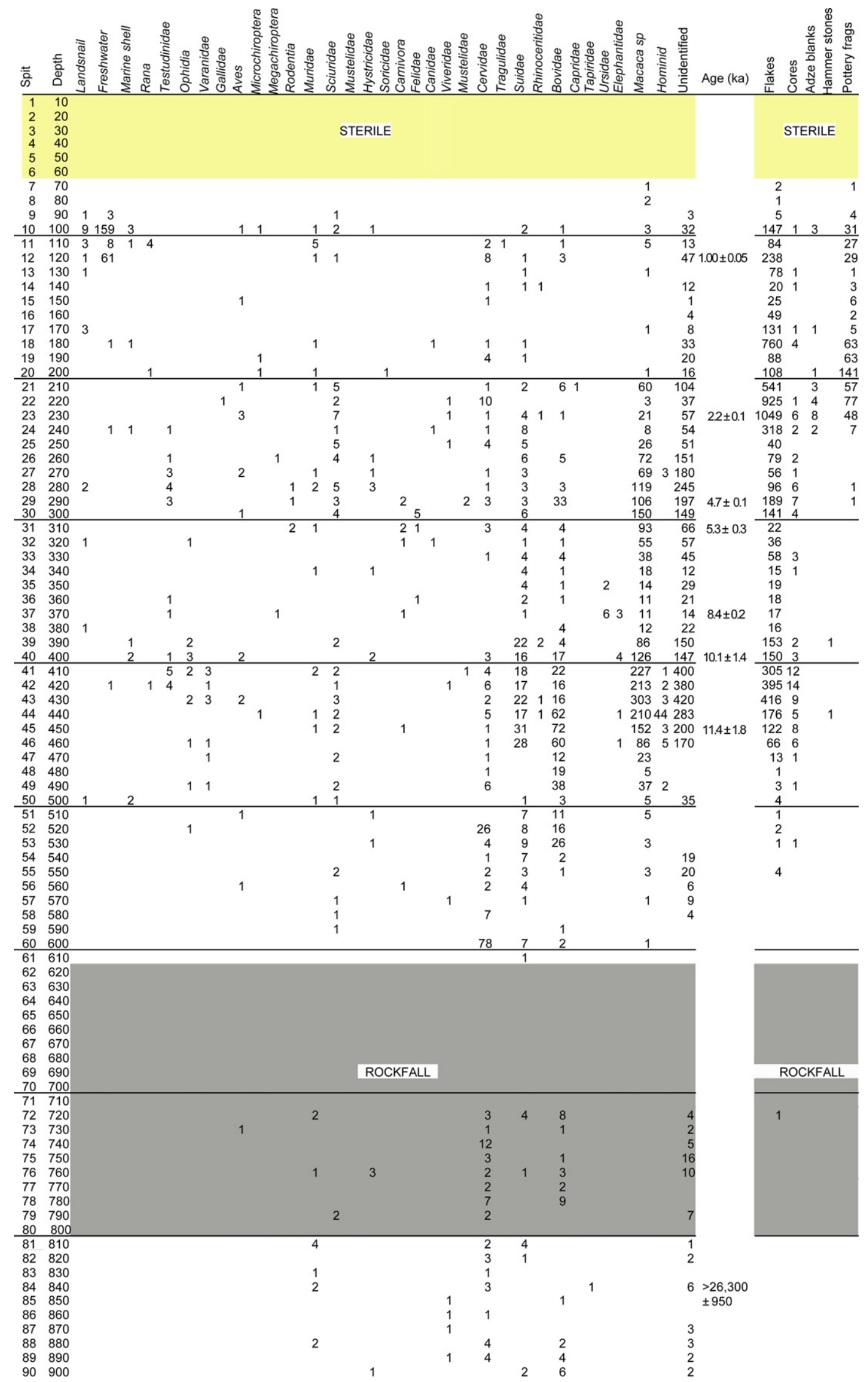

Diagnostic human remains only occurred from the terminal Pleistocene, and all were modern human, including the very robust skull of a child aged about 7 , who died 11,500 years ago. 
Table $2 b$

Right: stone artefacts and pottery fragments excavated from Sector I2, Song Gupuh

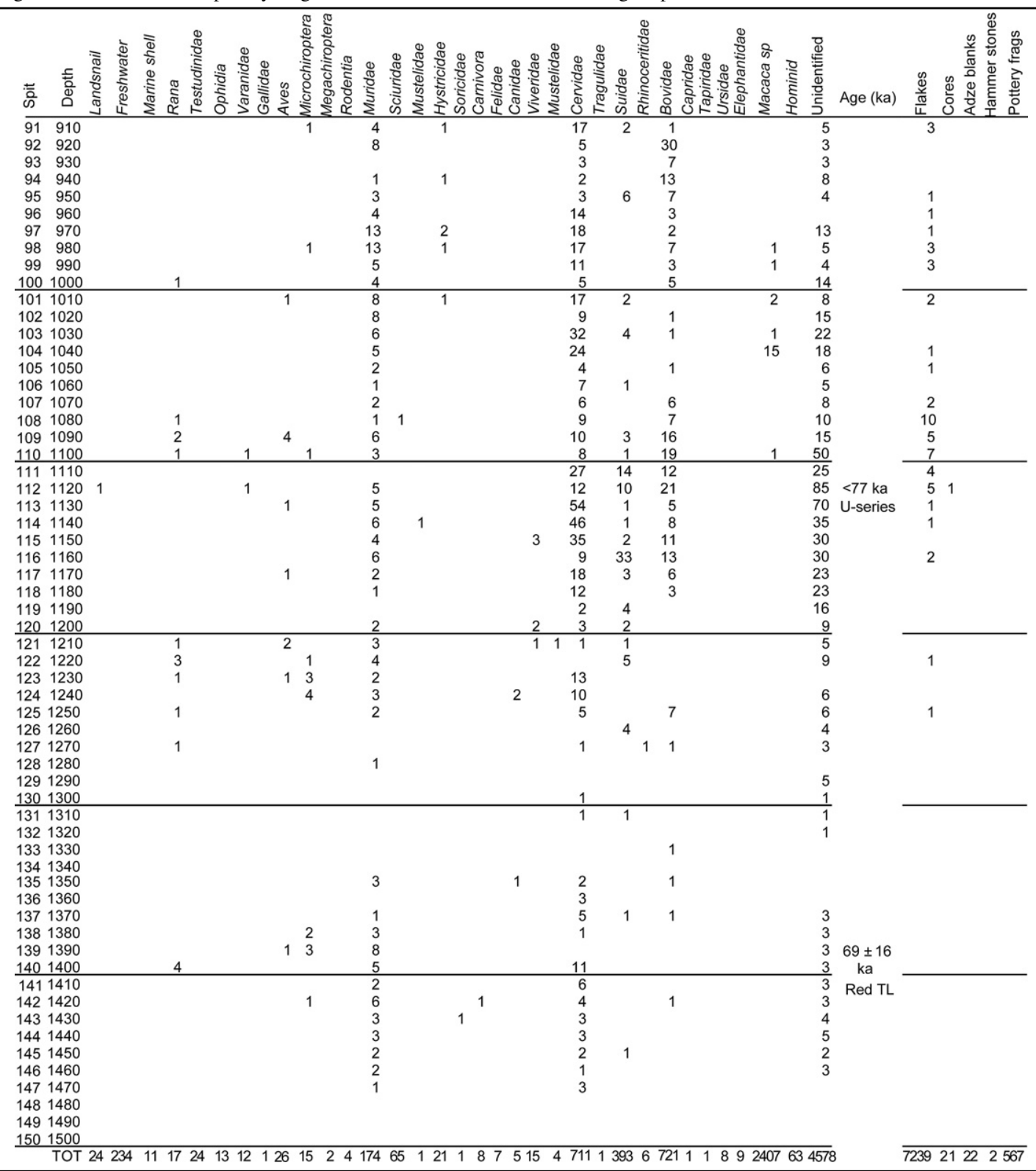

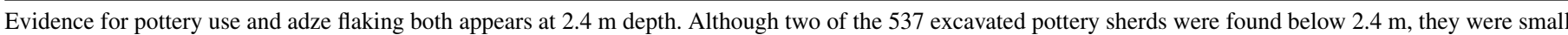
$(<1.7 \mathrm{~cm})$, and were almost certainly intrusive into gaps in the underlying limestone rockfall.

P6 yielded a total of 43 thick shells with step-fractured edge damage suggestive of scraping; 3 shell beads; and 80 bone tools, comprising 14 spatulas, 48 single points, 17 double points and a large point (Sutikna, 2001: Tables 13, 14; Fig. 7). The bone tools were made from a variety of anatomical elements including deer long bones and antlers; bovid long bones; carnivore ulnae; pig lower canines and humeri; and macaque upper canines, femurs, fibulae and ulnae. Two pieces of worked bone and a spatula made from palm wood were also found.

\section{Discussion}

The Song Gupuh sequence contains only extant fauna, but with species representation at any one time varying in response to the impacts of climate change and humans. For instance, the archaeological record shows that people intensified their use of the abundant animal resources from the Terminal Pleistocene, and continued hunting and gathering long after the arrival of the Neolithic and farming some $2.6 \mathrm{ka}$ years ago. The associated Holocene history of fauna in the region is clearly one of staggered species depletion due to human population growth and clearing for cultivation, as well as climate change. Elephant, bear and tapir all existed in the region until at least $5 \mathrm{ka}$, whereas rhino continued to within the last 1000 years. In fact, local informants say that rhino and tiger were present until early Dutch times, while macaque, pig, deer, cat, porcupine and leopard still occur in the general area. 


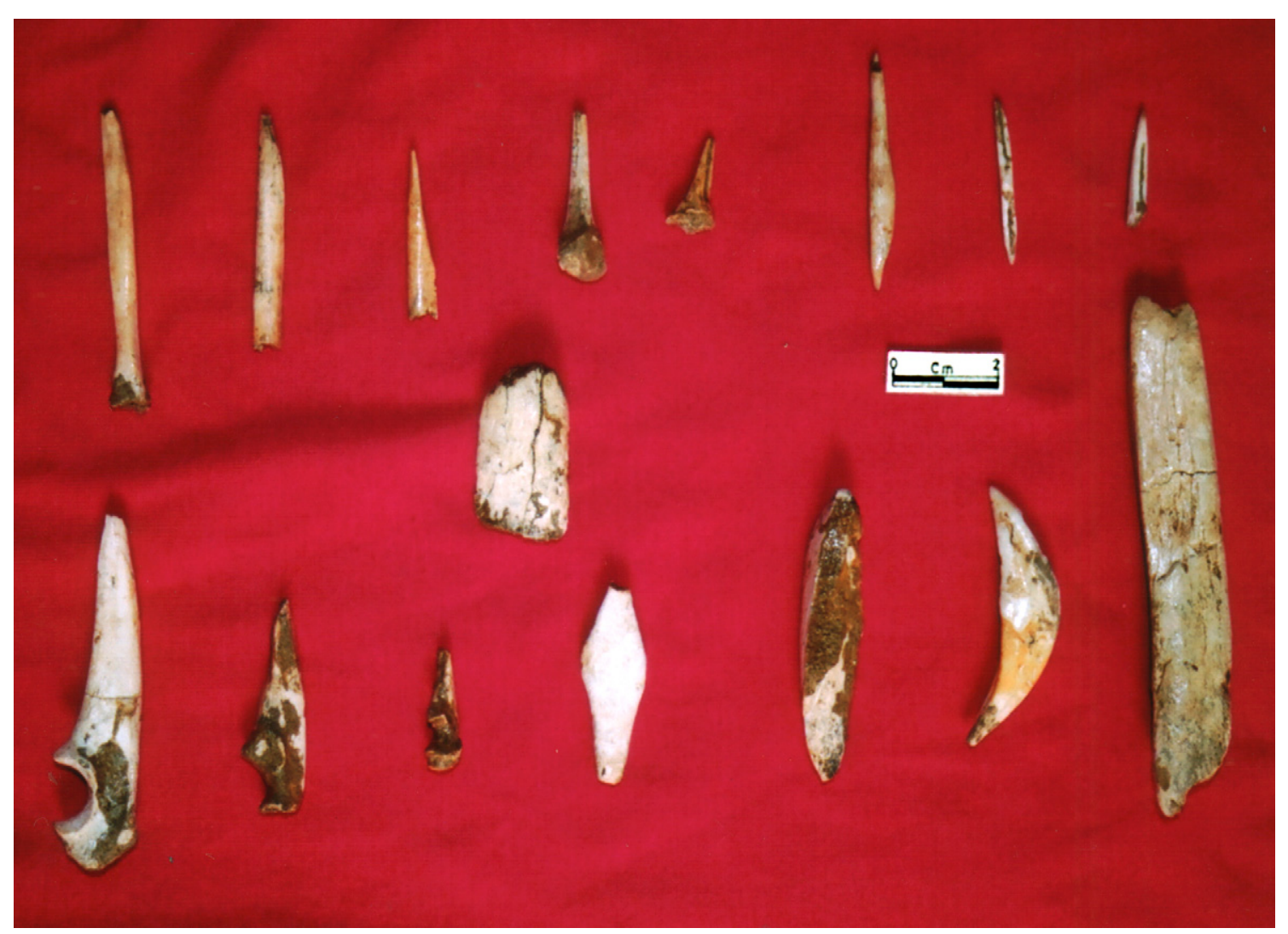

Fig. 7. Bone artefacts excavated from Sectors N4 and P6, Song Gupuh. These are associated with evidence for more intensive use of small-bodied animals from the terminal Pleistocene, specifically macaques and molluscs (photo: M.J. Morwood).

Similar Holocene faunal scenarios come from other sites in the region, but with minor differences depending on sample size and local circumstances. Wajak, for instance, contained no evidence for elephant, but yielded tiger (Panthera tigris), a species not represented at Song Gupuh; tapir is absent from the pre-Neolithic site of Sampung, but is dated to 2650 BP at Jimbe; and so on (Storm, 1995; Table 4). Further afield in West Java, there is evidence of elephant until 600 BP at Mauk (Rokus Awe Due, personal communication; see also Laufer, 1925), while localized populations of rhino still occur.

Going further back in time, the nearby Punung Breccia sites have yielded a faunal assemblage of early Last Interglacial age between $128 \pm 15$ and $118 \pm 3 \mathrm{ka}$ (Westaway et al., 2007a). Unlike earlier faunal sites in Java, these Late Pleistocene breccias contain no extinct mammals (Badoux, 1959; De Vos, 1983), but document the first known appearance on Java of a fully modern faunal suite, including elephant, sun bear, orangutan (Pongo pygmaeus), siamang and gibbon (Hylobates), and possibly modern humans (Storm et al., 2005). With the exception of the rainforest-dependant species, gibbon and orangutan, the same suite of animals occurs differentially in Gunung Sewu sites of Holocene age. Given that gibbon still occurs in West Java and that orangutan may have continued in more fertile parts of Java prior to extensive rainforest clearance for agriculture, it seems inappropriate to use the presence or absence of species at 'type' sites to subdivide the history of modern fauna in Java over the past $125 \mathrm{ka}$ into a series of island-wide stages.

The same can be said for the mammalian biostratigraphy of Java generally, which is currently divided into seven faunal stages identified on the basis of changes in faunal content at 'type' sites, stratigraphic relations and numerical age estimates. From oldest to youngest, these stages with their associated proboscideans, hominins and inferred ages comprise the Satir, Sinomastodon bumiajuensis (2.0-1.5 Ma); Ci Saat, Stegodon trigoncephalus, Homo erectus (1.2-1.0 Ma); Trinil H.K., Stegodon trigoncephalus, Homo erectus (0.9 Ma); Kedung Brebus, Stegodon trigoncephalus, Elephas hysudrindicus, Homo erectus (0.8-0.7 Ma); Ngandong, Stegodon trigoncephalus, Elephas hysudrindicus, Homo erectus (Late Pleistocene); Punung, Elephas maximus, Homo sapiens? (130-80 ka); and Wajak, Elephas maximus, Homo sapiens (10-6 ka) (Theunissen et al., 1990; Van den Bergh et al., 2001). This is a cumbersome construct, and will become even more so when faunal assemblages from other times and places are located and dated. Designated stages prior to the Punung Fauna, for instance, all relate to dry, glacial conditions, and there is no information currently available on the faunal history of Java during the many Early and Middle Pleistocene interglacials.

An alternate scheme based on the few known island-wide faunal changes, but anticipating considerable regional and site-specific variation, would actually be more useful-for 
instance, the general, three-part sequence of Sinomastodon, Stegodon-Homo erectus and Elephas maximus-Homo sapiens Faunas, as advocated by De Vos (1996). If biostratigraphic units are defined as polythetic species sets, with individual assemblages being subsets, as determined by local conditions, accessibility, historical events, taphonomy and sample size, then the faunal assemblage from Song Gupuh is best considered as part of the fully-modern fauna present on Java for the last $125 \mathrm{ka}$, with variation in species representation over time reflecting changes in a similar range of determining factors.

Wider comparisons between Song Gupuh and other dated faunal sites show how the nature, timing and direction of faunal sequences on different islands in the region also varied depending upon island accessibility, size, resource base, historical events and taphonomy (e.g. Van den Bergh, 1999; Louys et al., 2007). For instance, at Liang Bua on the oceanic island of Flores the extinction of the only large endemic mammals, Homo floresiensis and Stegodon florensis insularis, occurred $\sim 12 \mathrm{ka}$ (Morwood et al., 2004; Van den Bergh et al., in press), precisely the time when the range of large mammals at Song Gupuh on the continental island of Java peaked. In response, the first modern people at Liang Bua $\sim 11$ ka made more intensive use of plants, as signalled by the appearance in the Holocene archaeological record of heavy stone implements used for pounding and grinding, starch grains on artefacts and the absence of bone points-all in marked contrast with the Song Gupuh evidence. People on Flores also began to import useful species to supplement the island's relatively meagre resource base: by $7 \mathrm{ka}$ ago, the $\mathrm{Su}-$ lawesi warty pig (Sus celebensis) had been introduced, and with the coming of the Neolithic to the island around $4 \mathrm{ka}$ further introductions commenced. These included another type of pig (S. scrofa), dog, monkey, civet cat, porcupine and chicken. As a result, human impacts on Flores during the Holocene led to a marked increase in the range of large animals on the island, while in Java they resulted in a progressive reduction in biodiversity.

Comparisons between the palaeoenvironment, faunal, and archaeological records from sites with long stratified sequences, such as Leang Burung 2 in Sulawesi, Niah Cave in Sarawak, Tabon Cave on Palawan and Tham Lod in Thailand, can provide unexpected insights into past events and processes (e.g. Barker et al., 2007; Fox, 1970; Glover, 1981; Medway, 1972). It is worth noting, however, that the full extent and potential of the Song Gupuh sequence was only realized with use of deep trench excavations and application of a range of dating techniques (Fig. S3). As work at Liang Bua has similarly shown (e.g. Brown et al., 2004), use of such methods at other sites in Southeast Asia will better document the complexity of faunal evolution, dispersal and extinction in this remarkable region.

\section{Acknowledgements}

The work at Song Gupuh was funded by a grant from the Australian Research Council to M.J.M. We excavated there from 9th February to 25th March 2004 under Asisten Deputi
Urusan Arkeologi Nasional Permit Number 172/SB/ARNAS.II/05, and Badan Kesbang dan Linmas (Pacitan) Permit No. 072/159/408.45/2005; and from 9th February to 25th March 2004 under Asisten Deputi Urusan Arkeologi Nasional Permit Number 172/SB/ARNAS.II/05, and Badan Kesbang dan Linmas (Pacitan) Permit Number 072/159/408.45/2005. We thank the Director of the Indonesian National Research Centre for Archaeology, Dr Tony Djubiantono for his strong support. Gert van den Bergh, Phil Piper, Colin Groves and Penny Jordan all provided useful comments on earlier drafts.

\section{Appendix A. Supplementary data}

Supplementary data can be found, in the online version, at doi:10.1016/j.jas.2007.11.025.

\section{References}

Badoux, D.M., 1959. Fossil mammals from two fissure deposits at Punung (Java). PhD dissertation, University of Utrecht.

Barker, G., Barton, H., Bird, M., Daly, P., Datan, I., Dykes, A., Farr, L., Gilbertson, D., Harrison, B., Hunt, C., 2007. The 'human revolution' in lowland tropical Southeast Asia: the antiquity and behaviour of anatomically modern humans at Niah Cave (Sarawak, Borneo). Journal of Human Evolution 52, 243-261.

Bird, M.I., Ayliffe, L.K., Fifield, L.K., Turney, C.S.M., Cresswell, R.G., Barrows, T.T., David, B., 1999. Radiocarbon dating of "old" charcoal using a wet oxidation-stepped combustion procedure. Radiocarbon 41, 127-140.

Brown, P., Sutikna, T., Morwood, M.J., Soejono, R.P., Jatmiko, W., Saptomo, E., Rokus, D.A., 2004. A new small-bodied hominin from the Late Pleistocene of Flores, Indonesia. Nature 431, 1055-1061.

Fox, R.B., 1970. The Tabon Caves. National Museum Monograph, 1. National Museum of the Philippines, Manila.

Glover, I., 1981. Leang Burung 2: an Upper Palaeolithic rock shelter in South Sulawesi, Indonesia. Modern Quaternary Research in Southeast Asia 6, $1-38$.

Hogg, A.G., McCormac, F.G., Higham, T.F.G., Reimer, P.J., Baillie, M.G.L., Palmer, J.G., 2002. High-precision radiocarbon measurements of contemporaneous tree-ring dated wood from the British Isles and New Zealand: AD 1850-950. Radiocarbon 44, 633-640.

Hughen, K., Southon, J., Lehman, S., Bertrand, C., Turnbull, J., 2006. Marinederived ${ }^{14} \mathrm{C}$ calibration and activity record for the past 50,000 years updated from the Cariaco Basin. Quaternary Science Reviews 25, 3216-3227.

Ithara, M., Watanabe, N., Kadar, D., Kumai, H., 1994. Quaternary stratigraphy of the hominid fossil bearing formations in the Sangiran area, central Java. In: Frunzen, J.L. (Ed.), 100 years of Pithecanthropus: the Homo erectus Problem. Courier Forschungsinstitut Senckenberg, Frankfurt, pp. 123-128.

Laufer, B., 1925. Ivory in China. Field Museum of Natural History, Chicago, IL, Anthropology Leaflet No. 21.

Louys, J., Curnoe, D., Tong, H., 2007. Characteristics of Pleistocene megafauna extinctions in Southeast Asia. Palaeogeography, Palaeoclimatology. Palaeoecology 243, 152-173.

Medway, L., 1972. The Quaternary mammals of Malesia: a review. In: Ashton, P., Ashton, M. (Eds.), The Quaternary Era in Malesia Transactions of the Second Aberdeen-Hull Symposium on Malesian Ecology. University of Hull, Hull, pp. 63-83.

Morwood, M.J., Soejono, R.J., Roberts, R.G., Sutikna, T., Turney, C.S.M., Westaway, K.E., Rink, W.J., Zhao, J.-X., Van den Bergh, G.D., Rokus, D.A., Hobbs, D.R., Moore, M.W., Bird, M.I., Fifield, L.K., 2004. Archaeology and age of a new hominin species from Flores in eastern Indonesia. Nature 431, 1087-1091. 
Prasetyo, B., 2004. Juga industri tulang. In: Simanjuntak, H.T., et al. (Eds.), Prasejarah Gunung Sewu. Ikatan Ahli Arkeologi Indonesia, Jakarta, pp. 177-189.

Reimer, P.J., Baillie, M.G.L., Bard, E., Bayliss, A., Beck, J.W., Bertrand, C.J.H., Blackwell, P.G., Buck, C.E., Burr, G.S., Cutler, K.B., Damon, P.E., Edwards, R.L., Fairbanks, R.G., Friedrich, M., Guilderson, T.P., Hogg, A.G., Hughen, K.A., Kromer, B., 2004. IntCal04 terrestrial radiocarbon age calibration, 0-26 cal ka BP. Radiocarbon 46, 1029-1058.

Semah, F., Semah, A.M., Djubiantono, T., 1998. From the shoreline to the slopes of the volcanoes: the long Pithecanthropus trek. In: Simanjuntak, H.T., Prasetyo, B., Handini, R. (Eds.), Sangiran: Man, Culture and Environment in Pleistocene Times. Yayasan Obor Indonesia, National Research Centre of Archaeology and Ecole Francaise d'Extreme Orient, pp. 195-218.

Simandjuntak, T.O., Barber, A.J., 1996. Contrasting tectonic styles in the Neogene orogenic belts of Indonesia. In: Hall, R., Blundell, D.J. (Eds.), Tectonic Evolution of Southeast Asia. Geological Society Special Publication No. 106. The Geological Society, London, pp. 185-201.

Simanjuntak, H.T., Prasetyo, B., 2004. Hunian gua dan subsistensi. In: Simanjuntak, H.T., et al. (Eds.), Prasejarah Gunung Sewu. Ikatan Ahli Arkeologi Indonesia, Jakarta, pp. 139-152.

Storm, P., 1995. The evolutionary significance of the Wajak skulls. In: Scripta Geologica, 110. National Natuurhistorisch Museum, Netherlands.

Storm, P., Aziz, F., De Vos, J., Kosasih, D., Baskoro, S., Ngaliman, Van Den Hoek Ostende, L.W., 2005. Late Pleistocene Homo sapiens in a tropical rainforest fauna in East Java. Journal of Human Evolution 49, 536-545.

Sutikna, T., 2001. Permukiman Neolitik di daerah Punung, Pacitan, Jawa Timur: kasus di situs Song Gupuh. Unpublished MA thesis, University of Indonesia, Jakarta.

Theunissen, B., De Vos, J., Sondaar, P.Y., Aziz, F., 1990. The establishment of a chronological framework for the hominid-bearing deposits of Java; a historical survey. In: Laporte, L.F. (Ed.), Establishing a Geological Framework for Palaeoanthropology. Geological Society of America Special Paper, 242, pp. 39-54.

Turney, C.S.M., Bird, M.I., Fifield, L.K., Roberts, R.G., Smith, M.A., Dortch, C.E., Grun, R., Lawson, E., Ayliffe, L.K., Miller, G.H., 2001. Early human occupation at Devil's Lair, southwestern Australia 50,000 years ago. Quaternary Research 55, 3-13.
Van den Bergh, G., 1999. The late Neogene elephantoid-bearing fauna of Indonesia and their palaeozoogeographic implications: a study of the terrestrial fauna succession of Sulawesi, Flores and Java, including evidence for early hominid dispersal east of Wallace's Line. Scripta Geologica $117,1-419$.

Van den Bergh, G., De Vos, J., Sondaar, P.Y., 2001. The Late Quaternary palaeogeography of mammal evolution in the Indonesian Archipelago. Palaeogeography, Palaeoclimatology, Palaeoecology 171, 385-408.

Van den Bergh, G.D., Rokus, D.A., Morwood, M.J., Sutikna, T., Jatmiko, Saptomo, E.W. The youngest Stegodon remains in South-East Asia from the late Pleistocene Archaeological site Liang Bua, Flores, Indonesia. Quaternary International, in press.

De Vos, J., 1983. The Pongo faunas from Java and Sumatra and their significance for biostratigraphical and palaeoecological interpretations. Palaeontology Proceedings B 86 (4), 417-425.

De Vos, J., 1996. Faunal turnovers in Java in relation to faunas of the continent. Odontology 1, 32-36.

Von Koenigswald, G.H.R., 1939. Das Pleistocan Javas. Quartär 2, 28-53.

Westaway, K.E., 2006. Reconstructing the Quaternary landscape evolution and climate history of western Flores: an environmental and chronological context for an archaeological site. PhD thesis, University of Wollongong, Australia.

Westaway, K.E., Roberts, R.G., 2006. A dual-aliquot regenerative-dose protocol (DAP) for thermoluminescence (TL) dating of quartz sediments using the light-sensitive and isothermally-stimulated red emissions. Quaternary Science Reviews 25, 2513-2528.

Westaway, K.E., Morwood, M.J., Roberts, R.G., Rokus, D.A., Zhao, J.-X., Storm, P., Aziz, F., Van Den Bergh, G., Hadi, P., Jatmiko, De Vos, J., 2007a. Age and biostratigraphic significance of the Punung Rainforest Fauna, East Java, Indonesia, and implications for Pongo and Homo. Journal of Human Evolution 53, 709-717.

Westaway, K.E., Zhao, J.-X., Roberts, R.G., Chivas, A.R., Morwood, M.J., Sutikna, T., 2007b. Initial speleothem results from western Flores and eastern Java, Indonesia: were climate changes from 47 to $5 \mathrm{ka}$ responsible for the extinction of Homo floresiensis? Journal of Quaternary Science 22, 429-438.

Zhao, J.-X., Hu, K., Collerson, K.D., Xu, H.-K., 2001. Thermal ionization mass spectrometry $\mathrm{U}$-series dating of a hominid site near Nanjing, China. Geology 29, 27-30. 